JAKUB JAŹWIŃSKI

\title{
REPOZYTORIUM AGH - DOŚWIADCZENIA I POSTAWY PRACOWNIKÓW NAUKOWYCH AKADEMII GÓRNICZO- -HUTNICZEJ IM. STANISŁAWA STASZICA W KRAKOWIE
}

\section{Słowa kluczowe}

archiwizacja danych; repozytorium instytucjonalne; Repozytorium AGH; user experience

\section{Keywords}

archiving data; institutional repository; Repository of AGH; user experience

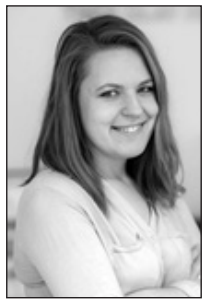

Paulina Strejczek-Jaźwińska, specjalista ds. informatyki w Samodzielnej Sekcji Komputeryzacji Biblioteki Głównej AGH w Krakowie. Zainteresowana zastosowaniami technologii w nauce oraz zoologią, szczególnie zagrożonym gatunkiem, jakim jest chomik europejski. Autorka m.in.: The results of the inventory of common hamster (Cricetus cricetus l.) sites conducted in małopolska voivodeship („Zoologica Poloniae”, t. 58, 2013).E-mail: paulina.jazwinska@bg.agh.edu.pl Jakub Jaźwiński, archiwista i administrator bazy dorobku naukowego Uniwersytetu Rolniczego w Krakowie. Doktorant w Instytucie Zarządzania Zasobami Leśnymi UR. Jego zainteresowania naukowe to historia leśnictwa oraz wycena pozaprodukcyjnych funkcji lasu ze szczególnym uwzględnieniem sportu, rekreacji oraz edukacji na terenach leśnych. Autor m.in. publikacji Leśnictwo jako dziedzina naukowa i jego paradygmat, („EPISTEME” 2016, nr 31). E-mail: jakub.jazwinski@urk.edu.pl

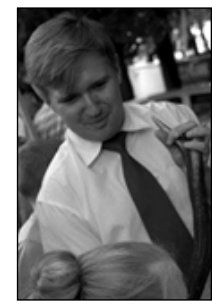




\section{Streszczenie}

Celem niniejszego opracowania jest przedstawienie wyników badań dotyczących doświadczeń oraz nastawienia pracowników naukowych środowiska akademickiego AGH do już istniejących repozytoriów i baz publikacji oraz ich stosunku do powstającego Repozytorium AGH. Badania oparte zostały o ankietę elektroniczną, która miała sprawdzić także jakie są oczekiwania środowiska akademickiego w stosunku do samego systemu oraz jego interfesju. Ankieta została przygotowana i opracowana za pomocą narzędzia LimeSurvey, które umożliwia udostępnienie jej w formie elektronicznej on-line, a następnie została przesłana e-mailem do wybranych grup naukowych. Przesłany e-mail zawierał treść zachęcającą do współpracy przy powstającym Repozytorium, link do ankiety oraz link do przygotowanych materiałów edukacyjnych dotyczących baz publikacji. Niniejsze opracowanie prezentuje wyniki, obserwacje oraz wnioski jakie nasunęły się podczas analizowania pozyskanych danych.

\section{Uwagi wstępne}

R) azy dorobku naukowego uczelni wyższych są jednym z głównych kanałów B) wymiany i prezentacji wyników badań prowadzonych przez jednostkę naukową. Repozytoria są nie tylko miejscem przechowywania pełnych tekstów publikacji pracowników naukowych uczelni, ale także stanowią miejsce prezentacji ich szerszemu gronu odbiorców. Prezentacja ta polega na wprowadzeniu do repozytorium jak największej liczby danych bibliograficznych, które może zobaczyć każdy użytkownik korzystający z repozytorium w dowolnym miejscu na świecie. Jednocześnie jest to możliwość porównywania badań prowadzonych w określonych obszarach tematycznych.

Z dużą pomocą w tych działaniach przychodzi nam internet. Najnowsze rozwiązania technologiczne umożliwiają naukowcom wykorzystanie szerokiego wachlarza sposobów zdobywania nowej wiedzy oraz usprawniają komunikację z innymi specjalistami: wyszukiwania, gromadzenia i porządkowania informacji; nabywania i uaktualniania własnej wiedzy, publikowania i recenzowania artykułów naukowych, współtworzenie tego samego artykułu w jednym czasie, uczestniczenie w projektach naukowych oraz eksperymentach a także rozbudowany system komunikacji pomiędzy naukowcami ${ }^{1}$.

Jednakże należy mieć świadomość, iż problem dostępności wygląda nieco inaczej w przypadku pełnych tekstów publikacji, co jest związane z umowami

${ }^{1}$ M. Stąporek, Organizacja i funkcjonalność wiarygodnego archiwum cyfrowego uczelni wyższej na Przykładzie Politechniki Krakowskiej, [w:] Wokót zagadnień trwałej ochrony zasobów cyfrowych, red. A. Januszko-Szakiel, Kraków 2013, s. 145-159. 
jakie zawierają autorzy, jak i same uczelnie z wydawnictwami. O ile nie ma problemu z publikacjami wydawanymi przez wydawnictwo danej uczelni, gdyż zazwyczaj uczelnie posiadają licencję otwartą, o tyle w przypadku autorów indywidualnych mogą one się pojawiać, stanowiąc poważne utrudnienia i ograniczenia na polu ich publikacyjnej działalności. Wśród wielu autorów pojawia się obawa przed niewłaściwym wykorzystywaniem ich materiałów bądź plagiatem czy kradzieżą danych. Stąd istotnym stało się podjęcie tego tematu, zwrócenie uwagi na niektóre jego aspekty, identyfikując je, pokazując ich zakres, a także ich rozmiar i konsekwencje. Ważnym elementem stała się także ocena i analiza aktywności pracowników naukowych przy tworzeniu repozytorium oraz ich motywacji do współuczestnictwa w podejmowanych w tym zakresie działaniach.

Celem artykułu jest pokazanie doświadczeń, oczekiwań i obaw związanych $\mathrm{z}$ repozytorium prac naukowych środowiska akademickiego AGH w Krakowie.

\section{Cel i metoda}

Badania ankietowe dotyczące doświadczeń i obaw związanych z repozytorium prac naukowych pracowników AGH zostały przeprowadzone w okresie od $23 \mathrm{~V}$ do 9 VI 2017 roku. Ankieta została opracowana i przeprowadzona w Zespole Repozytorium AGH działającym przy Bibliotece Głównej AGH.

Repozytorium AGH zostało uruchomione na otwartej platformie DSpace. Wybór został podyktowany danymi, aktualizowanymi przez Directory of Open Access Repositories ${ }^{2}$, które podają, że ponad 44\% repozytoriów na świecie jest obsługiwanych przez DSpace ${ }^{3}$.

Celem badania było poznanie doświadczeń oraz nastawienia pracowników naukowych środowiska akademickiego AGH do już istniejących repozytoriów oraz ich stosunku do powstającego Repozytorium AGH. Ankieta miała również sprawdzić jakie są oczekiwania środowiska akademickiego w stosunku do samego systemu oraz interfesju.

${ }^{2}$ Zob.: OpenDOAR. The Directory of Open Access Repositories, http://www.opendoar.org/onechart.php? cID = \&ctID = \&rtID = \& clID = \&IID = \&potID = \&rSoftWareName $=\&$ search $=\&$ groupby $=$ r.rSoftWareName $\&$ orderby $=$ Tally $\% 20$ DESC $\&$ chart type $=$ pie $\&$ width $=600 \&$ height $=300 \&$ caption $=$ Usage $\% 20$ of $\% 200$ pen $\% 20$ Access $\% 20$ Repository\%20Software\%20-\%20Worldwide (dostęp 10 X 2017 r.)

${ }^{3}$ Dane z dnia 10 X 2017 r. 
Ankieta została przygotowana i opracowana za pomocą narzędzia LimeSurvey, które umożliwia udostępnienie jej w formie elektronicznej on-line, a następnie została przesłana e-mailem do wybranych grup naukowych przy wykorzystaniu wewnętrznego sytemu SkOs, który zawiera dane wszystkich pracowników AGH z podziałem na grupy naukowe. Przesłany e-mail zawierał treść zachęcającą do współpracy przy powstającym Repozytorium, link do ankiety oraz link do przygotowanych materiałów edukacyjnych. Przedstawiały one korzyści jakie zwykle czerpią osoby, które deponują swoje publikacje w repozytoriach. Wiadomość wysłana została we wtorek 23 maja, około godzin południowych. Wysłano 2463 widomości e-mail.

Celem pośrednim było rozpropagowanie wśród środowiska akademickiego faktu stworzenia repozytorium i wskazania, że wszyscy będą mieli realny wpływ na jego wygląd i funkcjonowanie. Było to bardzo ważne, aby u progu działania repozytorium stworzyć jak najbardziej pozytywny odbiór samej idei. Ponieważ tylko wówczas, „kiedy idea znajdzie poparcie i odzew ze strony środowiska naukowego uczelni - praca osób powołanych do stworzenia platformy, opieki administracyjnej i redakcyjnej będzie owocna"4.

Tworząc badanie wykorzystano doświadczenia własne oraz ankietę badającą doświadczenia użytkowników pierwszego w Polsce repozytorium, stworzoną w 2013 r. przez Emilię Karwasińską i Małgorzatę Rychlik z Biblioteki Uniwersyteckiej z Uniwersytetu im. Adama Mickiewicza w Poznaniu ${ }^{5}$. Inspirowano się również zasadami budowania repozytorium na podstawie materiałów z 2012 r. ${ }^{6}$

\section{Struktura ankiety}

Ankieta miała charakter anonimowy, składała się z 3 części głównych, które łącznie zawierały 20 pytań zamkniętych ze sporadyczną możliwością swobodnego komentowania. Pytania miały przynieść odpowiedzi na temat zasadności utworzenia Repozytorium AGH, jego potencjalnej zawartości, osób zarządzają-

${ }^{4}$ E. Karwasińska, M. Rychlik, Model i etapy tworzenia repozytorium instytucjonalnego na podstawie badań własnych i doświadczeń bibliotek zagranicznych, 2008, [w:] Informacja dla nauki a świat zasobów cyfrowych, red. H. Ganińska, Poznań 2008.

${ }^{5}$ E. Karwasińska, M. Rychlik, Doświadczenia z funkcjonowania pierwszego $w$ Polsce repozytorium instytucjonalnego na Uniwersytecie im. Adama Mickiewicza w Poznaniu, http://hdl.handle.net/10593/6498 (dostęp 10 X 2017 r.)

${ }^{6}$ E. Karwasińska, M. Rychlik, Budowanie repozytorium, http://hdl.handle.net/105 93/2874 (dostęp 10 X 2017 r.) 
cych, obaw, jakie są z nim związane, motywacji do deponowania swoich prac w repozytoriach oraz chęci współpracy przy tworzeniu Repozytorium AGH.

Część pierwsza zawierała pytania obligatoryjne, które zawierały dane potrzebne do zestawień statystycznych tj. wiek respondenta, grupa naukowa jaką reprezentuje, liczba lat pracy na uczelni, główne miejsce pracy oraz dwa pytania ogólne dotyczące znajomości pojęcia „repozytorium instytucjonalne” oraz zapoznania się z podanymi w e-mailu materiałami edukacyjnymi.

Część druga zawierała 11 pytań badających nastawienie, doświadczenia oraz postawy związane zarówno z powstającym repozytorium, jak i z innymi repozytoriami lub miejscami deponowania swojej pracy naukowej.

Cześć ostatnia zawierała pytania dodatkowe, które przyniosły odpowiedzi dotyczące zakresu ewentualnej pomocy oraz współpracy, a także wskazały wiele cennych uwag dotyczących przyszłego funkcjonowania Repozytorium AGH.

\section{Omówienie wyników badań}

Część 1. Charakterystyka osób biorących udział w badaniu

W badaniu wzięło udział 304 respondentów. 246 (10\% z całej grupy wysłanych wiadomości e-mail) osób zakończyło ankietę, natomiast 54 osoby porzuciły ankietę na początku lub w połowie wypełniania - najprawdopodobniej z powodu braku czasu.

Najliczniejsze dwie grupy stanowili ludzie do 35 roku życia oraz pomiędzy 36 a 45 (obydwie grupy 83 osoby, 34 \%). Następnie osoby w wieku 46-55 lat (40 osób, 16\%), 56-65 (21 osób, 9\%) oraz powyżej 65 roku życia (19 osób, 8\%).

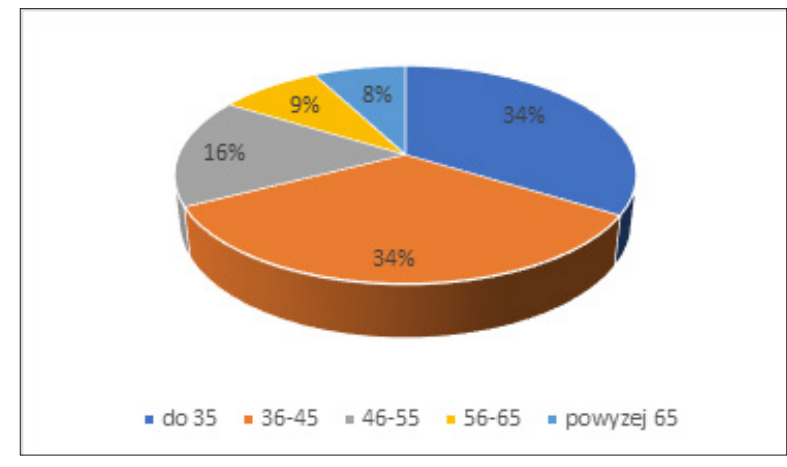

Ryc. 1. Wiek respondentów ankiety 
Najliczniejszą oraz najbardziej aktywną grupą naukową okazali się doktorzy (w tym doktor oraz doktor inżynier), którzy stanowili aż 56\% (138 osób) przebadanych respondentów, którzy ukończyli ankietę. W następnej kolejności uplasowali się doktorzy habilitowani (w tym doktor habilitowany oraz doktor habilitowany inżynier), którzy stanowili 19\% wszystkich respondentów (34 osoby), profesorowie (w tym profesor doktor habilitowany oraz profesor doktor habilitowany inżynier) - 12\% (29 osób) oraz doktoranci - 11\% (26 osób). 6 osób (2\%) zaliczyło się do grupy INNI. Można przypuszczać, że wśród nich są pracownicy AGH, którzy nie są związani z żadną z powyższych grup naukowych i posiadają inny tytuł naukowy.

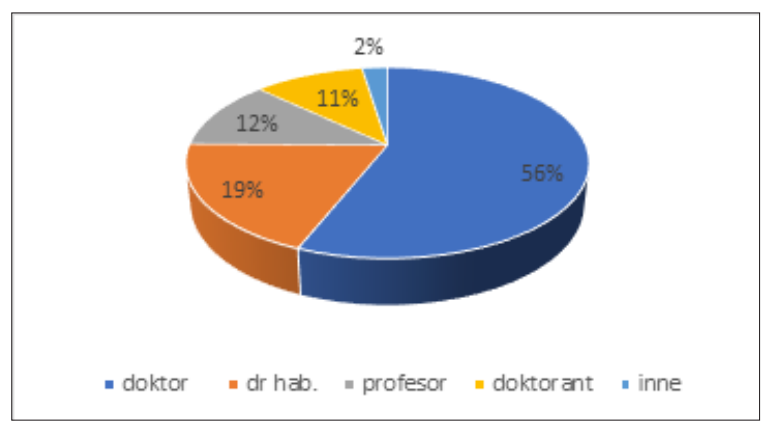

Ryc. 2. Grupy respondentów, którzy ukończyli ankietę.

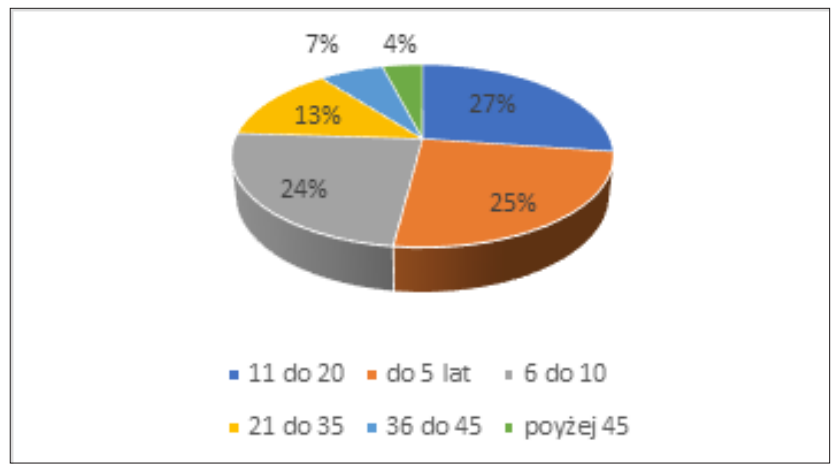

Ryc. 3. Liczba lat pracy na $A G H$

Jak widać na powyższym wykresie, najwięcej respondentów uplasowało się w grupie 11-20 lat pracy na AGH - 67 osób (27\%). Następnie w kolejności widzimy osoby do 5 lat pracy - 61 (25\%), od 6 do 10 lat pracy - 59 osób (24\%), 
od 21 do 35 lat pracy - 33 (13\%), od 36 do 45 lat pracy - 16 (7\%) oraz powyżej 45 lat pracy - 10 osób (4\%).

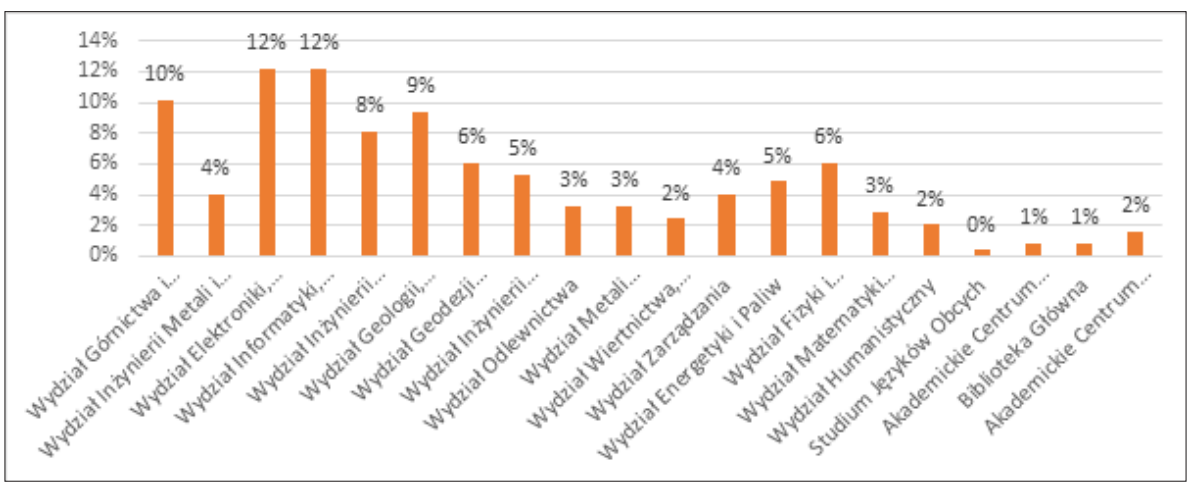

Ryc. 4. Główne miejsce pracy oraz aktywność poszczególnych wydziałów w wypełnianiu ankiety.

Najaktywniejszymi wydziałami okazały się Wydział Elektroniki, Automatyki, Informatyki i Inżynierii Biomedycznej oraz Wydział Informatyki, Elektroniki i Telekomunikacji - obydwa po 30 osób (12\%). Następnie uplasował się Wydział Górnictwa i Geoinżynierii - 25 osób (10\%), Wydział Geologii, Geofizyki i Ochrony Środowiska - 23 osoby (9\%) oraz Wydział Inżynierii Mechanicznej i Robotyki - 20 osób (8\%). Reszta wydziałów pokazana jest na powyższym wykresie.

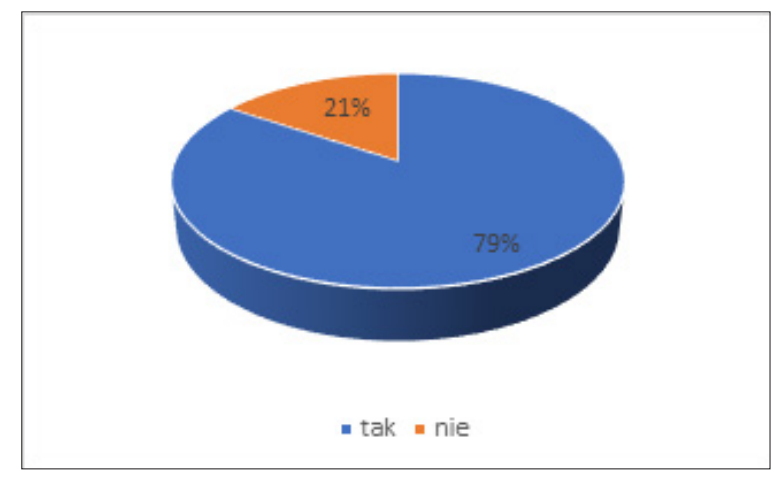

Ryc. 5. Dane dotyczące odpowiedzi na pytanie: Czy wie Pani/Pan co to jest repozytorium instytucjonalne? 
Ponad 79\% (195 osób) ankietowanych znało pojęcie „repozytorium instytucjonalne". To pokazuje nam, że świadomość dotycząca repozytoriów jest na w miarę zadowalającym poziomie.

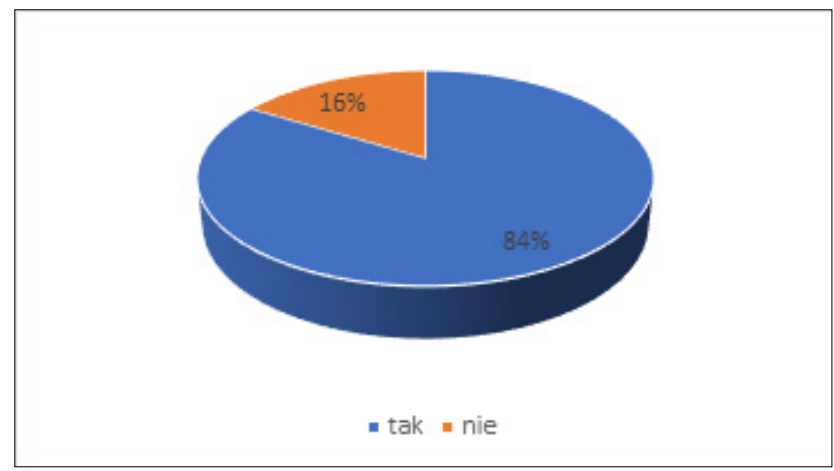

Ryc. 6. Dane dotyczące odpowiedzi na pytanie:

Czy zapoznała się Pani/Pan z przesłanymi materiałami?

84\% (206 osób) ankietowanych zapoznało się z przesłanymi materiałami. Wśród respondentów odpowiadających na dwa ostatnie pytania zaobserwowano ciekawe zależności. Zauważono, że znaleźli się zarówno tacy, którzy odpowiedzieli negatywnie na obydwa z nich (21 osób) jak i osoby, które nie wiedziały co to jest repozytorium, a zapoznały się z przesłanymi materiałami (16 osób). Oznacza to, że ankieta spełniła również funkcję edukacyjną.

Część 2. Badanie właściwe

Pytanie nr 1. Czy kiedykolwiek publikowała Pani / publikował Pan swoje prace $w$ Internecie?

- Serwisie społecznościowym dla naukowców np. researchgate.net, academia.edu itd.

- W czasopiśmie elektronicznym.

- Na własnej stronie www.

- W innym repozytorium.

- Na stronie wydziału / instytutu / zakładu.

- W innej bazie dorobku naukowego.

- W bibliotece cyfrowej.

_ Nie publikowałam / Nie publikowałem. 


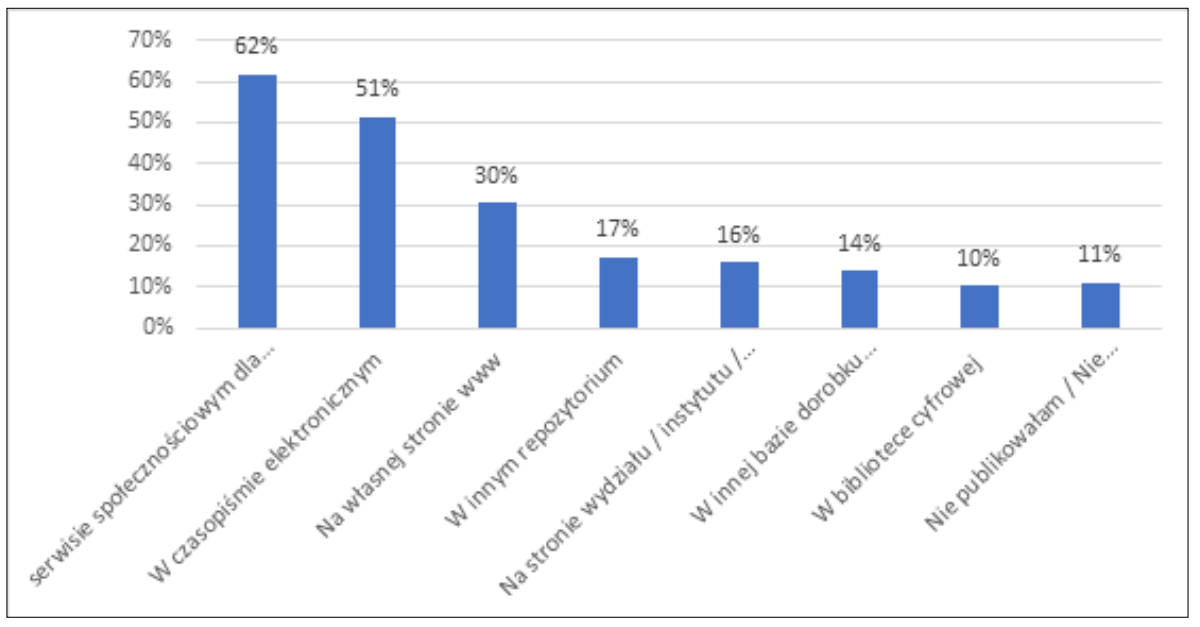

Ryc. 7. Dane dotyczące odpowiedzi na pytanie:

Czy kiedykolwiek publikowała Pani / publikowat Pan swoje prace $w$ Internecie?

Wśród respondentów najczęstszym miejscem wymienianym podczas odpowiedzi był serwis społecznościowy dla naukowców - odpowiedź taką wskazało 152 osoby czyli 62\% ankietowanych. Najczęściej wymienianym serwisem był serwis researchGate.net. Następnie ankietowani wymieniali czasopisma elektroniczne (51\%, 126 osób), własną stronę internetową (30\%, 75 osób), inne repozytorium (17\%, 42 osoby) oraz stronę własnego wydziału, instytutu, zakładu (16\%, 39 osób). Pośród grup naukowych najbardziej aktywni byli doktorzy, których ponad $60 \%$ wymieniła pierwsze trzy z najczęściej wymienianych opcji pytania.

Pytanie nr 2. Czy spotkała się Pani / spotkał się Pan wcześniej z pojęciem „Open Access” lub „Otwarty Dostęp do Wiedzy”?

$$
\text { - tak, }
$$

Wiedza na temat otwartego dostępu do wiedzy wśród badanych grup jest bardzo dobra - 231 osób, czyli prawie 94\% ankietowanych spotkała się z tym terminem i wie co to jest. Wśród osób, które odpowiedziały przecząco nie występowała przeważająca liczba respondentów z konkretnej grupy naukowej. 


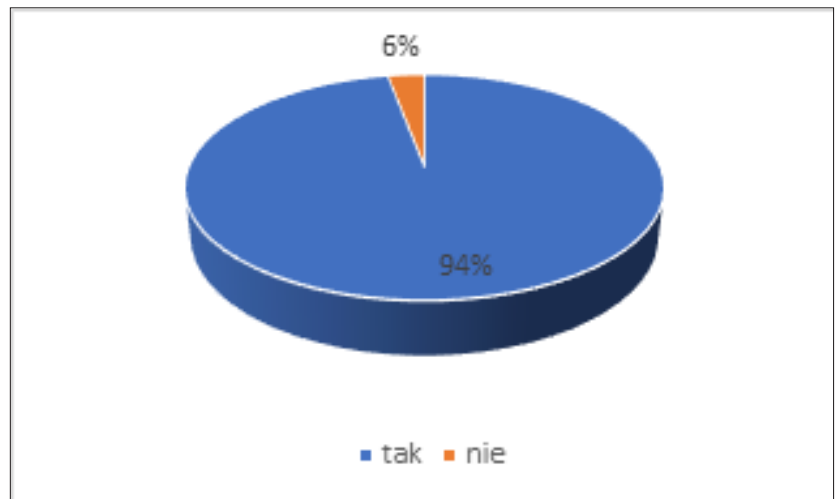

Ryc. 8. Odpowiedź na pytanie: Czy spotkała się Pani / spotkat się Pan wcześniej z pojęciem „Open Access” lub „Otwarty Dostęp do Wiedzy”?

Pytanie nr 3. Jakiego typu prace wg Pani / Pana powinny być deponowane $w$ powstajacym Repozytorium AGH?

- $\quad$ artykuły naukowe w postaci post i preprintów,

- rozprawy doktorskie i habilitacyjne,

- materiały konferencyjne,

- monografie,

- podręczniki,

- materiały dydaktyczne (wykłady, e-learning),

- prace dyplomowe

- raporty z badań lub projektów,

- zdigitalizowane dokumenty o wartości historycznej,

- opisy patentowe,

- materiały niepublikowane,

- dokumenty AGH,

- zdjęcia,

- obiekty, dane badawcze,

- filmy,

- multimedialne katalogi wystaw,

- inne. 


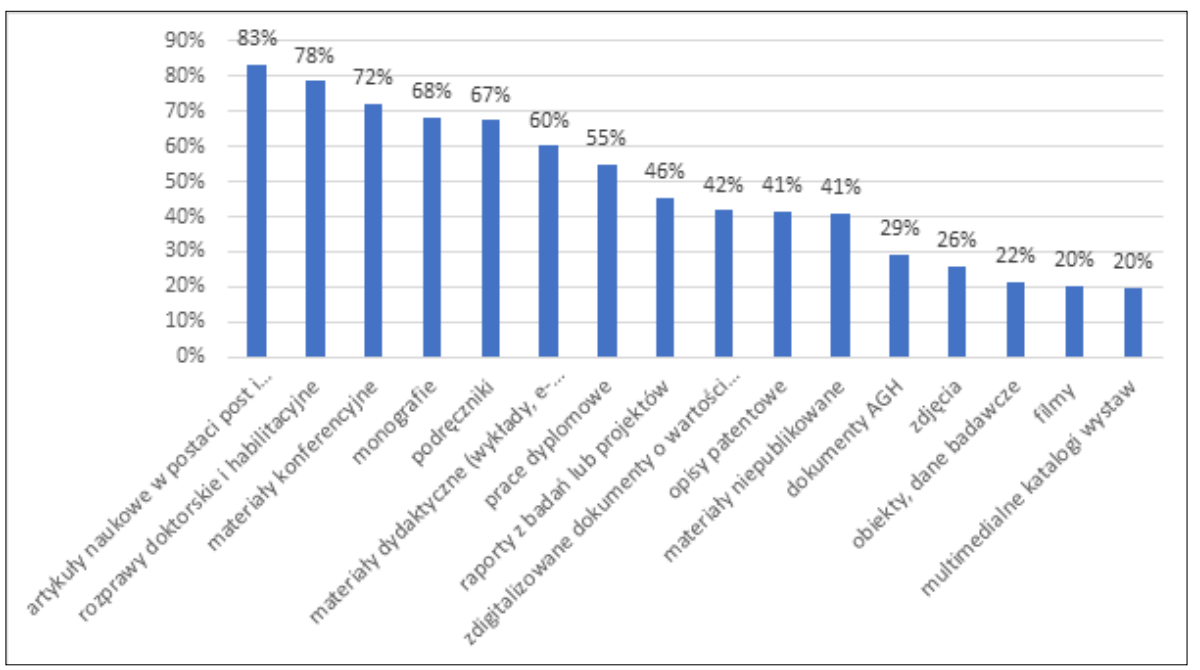

Ryc. 9. Odpowiedź na pytanie: Jakiego typu prace wg Pani /

Pana powinny być deponowane w powstajacym Repozytorium AGH?

Respondenci najchętniej w Repozytorium AGH widzieliby artykuły naukowe w postaci post i preprintów (205 osób, 83\%). Na drugim miejscu znajdują się rozprawy doktorskie i habilitacyjne (193 osoby, 78\%), a następnie materiały konferencyjne (72\%, 177 osób), monografie (68\%, 168 osób) i podręczniki (67\%, 166 osób). Na dalszych miejscach znalazły się materiały dydaktyczne (60\%, 148 osób), prace dyplomowe (55\%, 135 osób), raporty z badań lub projektów (46\%, 112 osób), zdigitalizowane dokumenty o wartości historycznej (42\%, 103 osoby), opisy patentowe (41\%, 102 osoby), materiały niepublikowane (41\%, 101 osób), dokumenty AGH (29\%, 72 osoby), zdjęcia (26\%, 64 osoby), obiekty badawcze (22\%, 53 osoby), filmy (20\%, 50 osób) oraz multimedialne katalogi wystaw (49 osób, 20\%). Rycina nr 9 przedstawia ogólny rozkład odpowiedzi. Respondenci wymienili również: wykłady, nagrania radiowe, tutoriale, ofertę badawczą, załączniki do artykułów w postaci kodów źródłowych wraz z danymi oraz kody źródłowe oprogramowania rozwijanego przez badacza.

Pytanie 4. W jaki sposób, zdaniem Pani / Pana prace opublikowane w repozytorium powinny być dostępne?

- powinny być dostępne dla wszystkich bez ograniczeń,

- powinny być dostępne dla zdefiniowanej grupy odbiorców, 
- powinny być dostępne dla wszystkich, z możliwością wskazania przez autora daty publikacji,

- powinny być dostępne tylko dla mnie, jako dokumentacja mojej działalności.

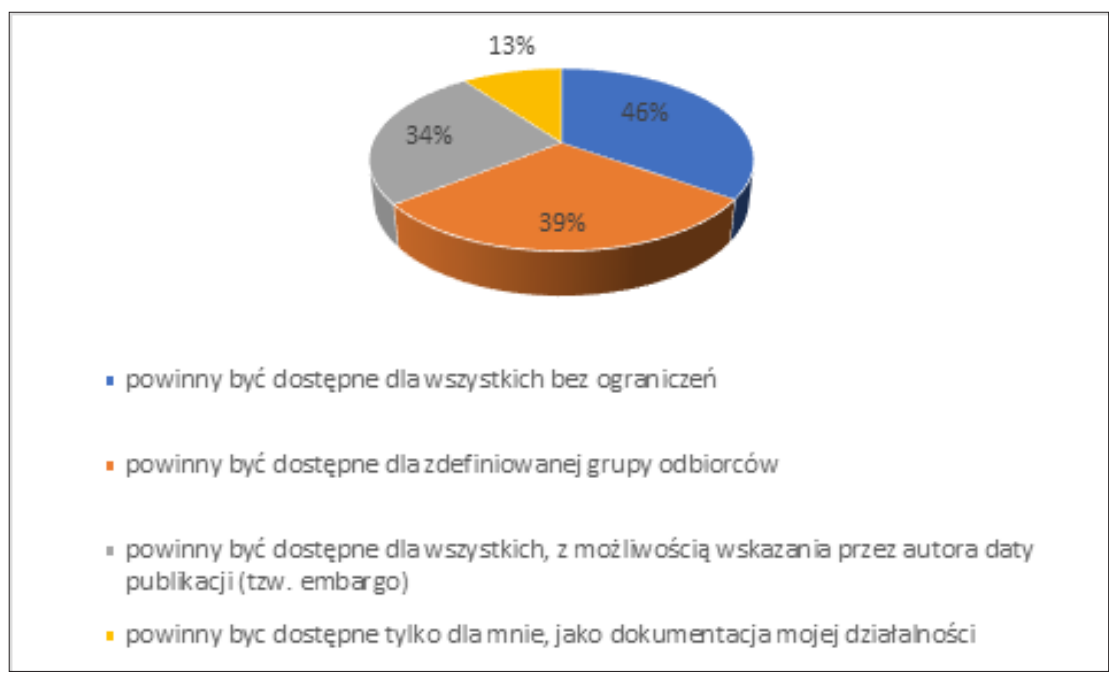

Ryc. 10. Odpowiedź na pytanie: W jaki sposób, zdaniem Pani / Pana prace opublikowane w repozytorium powinny być dostępne?"

Respondenci uważają, że prace opublikowane w repozytorium powinny być dostępne dla wszystkich bez ograniczeń (46\%, 114 osób). 39\% ankietowanych (97 osób) opowiedziało się za udostępnieniem, ale dla zdefiniowanej grupy odbiorców, 34\% (84 osoby) wolałyby wskazywać datę udostępnienia publikacji, natomiast 13\% czyli 33 osoby wolałyby udostępniać swoje prace tylko sobie, jako dokumentację swojej twórczości. Wśród grup naukowych za dostępnością bez ograniczeń opowiedziało się 18 profesorów (16\% odpowiedzi) co stanowi ponad $62 \%$ wszystkich profesorów, natomiast doktorzy uważają zarówno, że prace powinny być dostępne bez ograniczeń (44\% doktorów) jak i dostępne dla zdefiniowanej grupy odbiorców (również 44\% doktorów).

Pytanie 5. Czy w Pani / Pana odczuciu, autoarchiwizacja prac przez pracowników naukowych powinna być:

- obowiązkowa,

- nieobowiązkowa? 


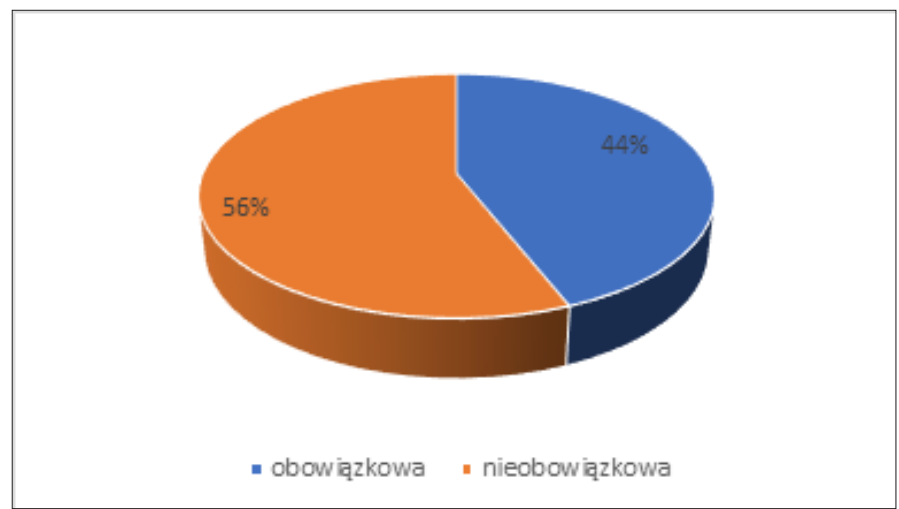

Ryc. 11. Odpowiedź na pytanie: Czy w Pani / Pana odczuciu, autoarchiwizacja prac przez pracowników naukowych powinna być: obowiqzkowa czy nieobowiqzkowa"

Według respondentów autoarchiwizacja powinna być nieobowiązkowa. Stwierdziło tak 56\% ankietowanych w tym: 33 \% doktorów, 10\% doktorów habilitowanych, $8 \%$ profesorów, 4\% doktorantów oraz $0,9 \%$ osób z innych grup naukowych.

Pytanie 6. Proszę podać 5 najważniejszych powodów, które skłonityby Panią / Pana do deponowania swoich prac $w$ repozytorium:

- wzrost cytowań,

- trwałe zabezpieczenie dokumentu, archiwizacja dokumentu, niezmienny adres dostępu,

- zwiększenie widoczności pracy w środowisku naukowym,

- promocja osiągnięć autora i jednostki macierzystej,

- szybkie upowszechnienie wyników pracy,

- wymiana doświadczeń, kontakty międzynarodowe,

- rozwój kariery zawodowej,

- nieograniczony dostęp do swoich dokumentów,

- wspieranie procesów edukacyjnych,

- rzetelna informacja o dokumencie,

- premia za liczbę publikacji wprowadzonych do repozytorium,

- kryterium otrzymania grantu,

- inne. 


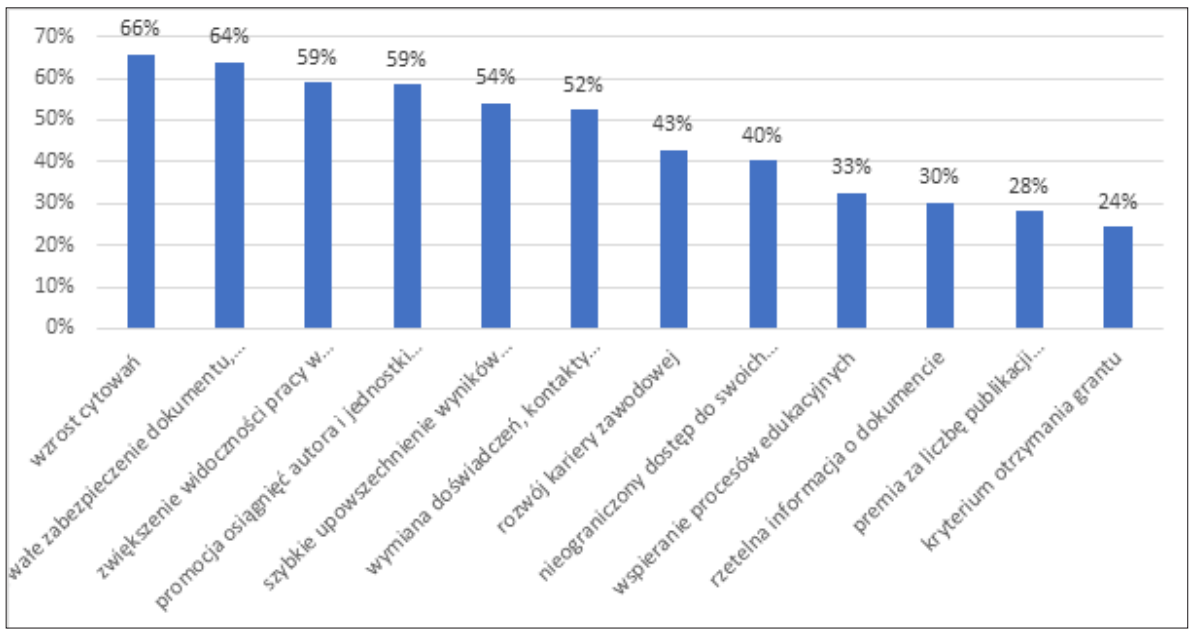

Ryc. 12. Odpowiedź na pytanie: Proszę podać 5 najważniejszych powodów, które skłoniłyby Paniq / Pana do deponowania swoich prac $w$ repozytorium

Najważniejszy powód, który nakłoniłby respondentów do deponowania prac w repozytorium to wzrost cytowań. Za ta opcją opowiedziało się 162 osoby, czyli $66 \%$ ankietowanych. Ważną rzeczą jest także trwałe zabezpieczenie dokumentu (157 osób, 64\%), zwiększenie widoczności pracy w środowisku naukowym oraz promocja osiągnięć autora i jednostki macierzystej (odpowiedni 145 i 144 osób, 59\%), a także szybkie upowszechnienie wyników pracy (133 osoby, 54\%). Na dalszych miejscach znalazła się wymiana doświadczeń i kontakty międzynarodowe (129 osób, 52\%), rozwój kariery zawodowej (105 osób, 43\%), nieograniczony dostęp do swoich dokumentów (99 osób, 40\%), wspieranie procesów edukacyjnych (80 osób, 33\%), rzetelna informacja o dokumencie (74 osoby, $30 \%$ ), premia za liczbę publikacji wprowadzonych do repozytorium (69 osób, $28 \%$ ) oraz kryterium otrzymania grantu (60 osób, 24\%).

Pytanie 7: Czy chciałaby Pani / chciałby Pan, aby w przyszłości w Repozytorium AGH istniały dodatkowe funkcjonalności umożliwiające bezpośrednia wymiane informacji pomiędzy użytkownikiem repozytorium a autorem? Jeżeli tak, proszę określić ich rodzaj:

- możliwość dodania komentarza do konkretnej pracy (po weryfikacji autora), 
- możliwość wysłania wiadomości do danego autora bezpośrednio przez system,

- możliwość podłączenia wtyczek społecznościowych np. Twitter, LinkedIn, Facebook,

- nie chciałabym/ nie chciałbym.

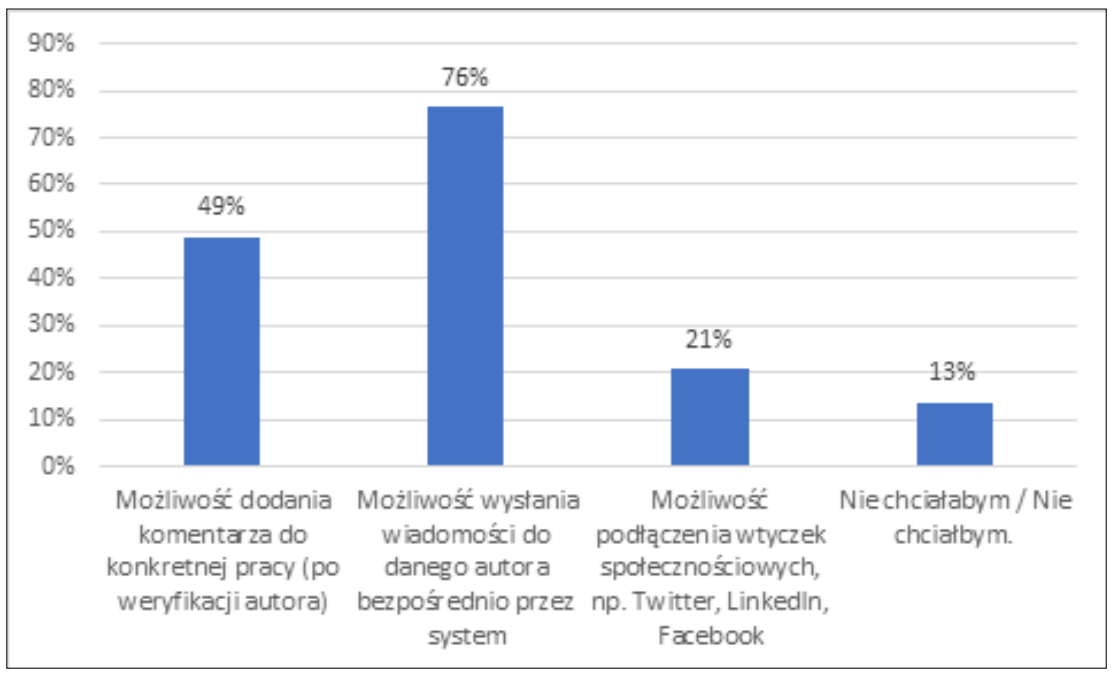

Ryc. 13. Odpowiedź na pytanie: Czy chciałaby Pani/chciałby Pan, aby w przyszłości w Repozytorium AGH istniały dodatkowe funkcjonalności umożliwiajqce bezpośredniq wymianę informacji pomiędzy użytkownikiem repozytorium a autorem? Jeżeli tak, proszę określić ich rodzaj

Najwięcej respondentów chciałby, aby w systemie była możliwość wysłania wiadomości do autora bezpośrednio przez system. Za taką opcją opowiedziało się 188 (76\%) ankietowanych. Na drugim miejscu znalazła się możliwość dodania komentarza do konkretnej pracy - 120 ankietowanych (49\%), 21\% ankietowanych potrzebuje wtyczek społecznościowych, a 13\% nie potrzebuje żadnych modyfikacji.

Pytanie 8: Proszę wskazać 3 najistotniejsze obawy przed umieszczeniem publikacji $w$ Repozytorium AGH:

- plagiat i nieuprawnione wykorzystanie wyników badań,

- niewystarczająca znajomość zagadnień prawnych związanych z publikacją prac w Internecie, 
- $\quad$ konieczność wygospodarowania dodatkowego czasu do nauki systemu i wprowadzania swoich publikacji,

- utrudnienie publikowania u wydawców komercyjnych,

- niewystarczające zabezpieczenia danych osobowych,

- problemy techniczne związane z zamieszczaniem prac,

- niewystarczające zabezpieczenie prac o ograniczonym dostępie,

- zmniejszenie zainteresowania studentów wykładami na uczelni,

- niechętny stosunek przełożonych, recenzentów, współautorów do tego modelu udostępniania,

- inne.

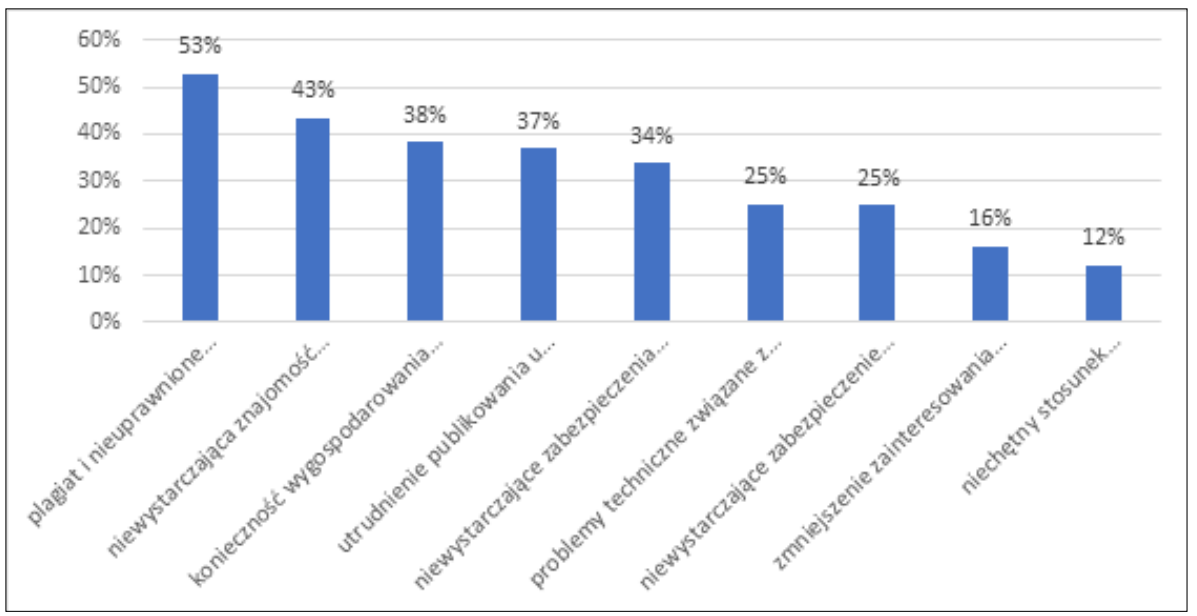

Ryc. 14. Odpowiedź na pytanie: Proszę wskazać 3 najistotniejsze obawy przed umieszczeniem publikacji w Repozytorium AGH

Trzema najistotniejszymi obawami przed umieszczaniem publikacji w repozytorium są: plagiat i nieuprawnione wykorzystanie wyników badań. W taki sposób odpowiedziała ponad połowa ankietowanych (130 osób, 53\%). Na drugim miejscu stoi niewystarczająca znajomość zagadnień prawnych związanych z publikacją prac w Internecie (94 osoby, 38\%), a na trzecim konieczność wygospodarowania dodatkowego czasu do nauki systemu i prowadzania swoich publikacji. Na dalszych miejscach znalazły się: utrudnienie publikowania u wydawców komercyjnych (91 osób, 37\%), niewystarczające zabezpieczenie danych osobowych (83 osoby, 34\%), problemy techniczne związane z zamieszczaniem prac (62 osoby, 25\%), niewystarczające zabezpieczenie prac o ograniczonym 
dostępie (61 osób, 25\%), zmniejszenie zainteresowania studentów wykładami uczelni (40 osób, 16\%) oraz niechętny stosunek przełożonych, recenzentów, współautorów do tego modelu udostępniania.

Pytanie 9: Kto Pani / Pana zdaniem powinien umieszczać publikacje $w$ repozytorium?

- autorzy,

- redaktorzy repozytorium w Bibliotece Głównej,

- redaktorzy repozytorium na Wydziałach.

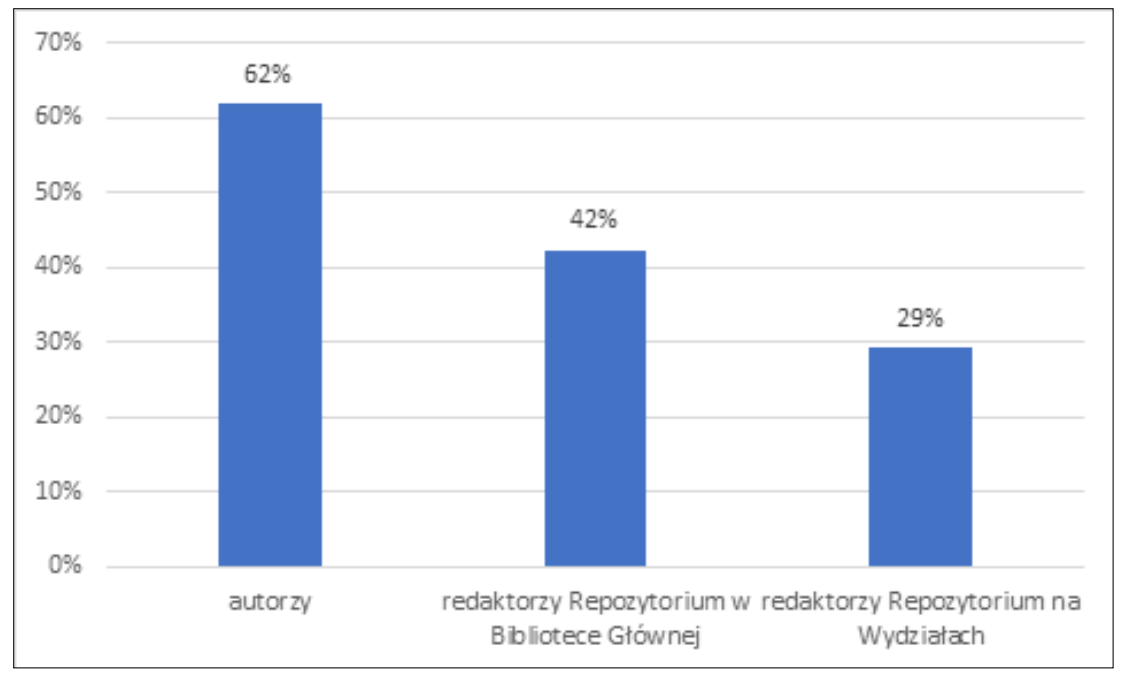

Ryc. 15 Odpowiedź na pytanie: Kto Pani / Pana zdaniem powinien umieszczać publikacje $w$ repozytorium?

Respondenci najchętniej chcieliby sami wprowadzać publikacje do repozytorium - w taki sposób odpowiedziało ponad $62 \%$ ankietowanych - 152 osoby. Na drugim miejscu znaleźli się redaktorzy w Bibliotece Głównej (104 osoby, 42\%) oraz redaktorzy na Wydziałach (72 osoby, 29\%).

Pytanie 10: Proszę dokończyć zdanie: „Repozytorium uczelniane uważam za: ...

- przydatne dla stworzenia odpowiednich warunków prawnych i zabezpieczeń technicznych, 
- przydatne,

- konieczne,

- zbędne (pomimo zaleceń MNiSW).

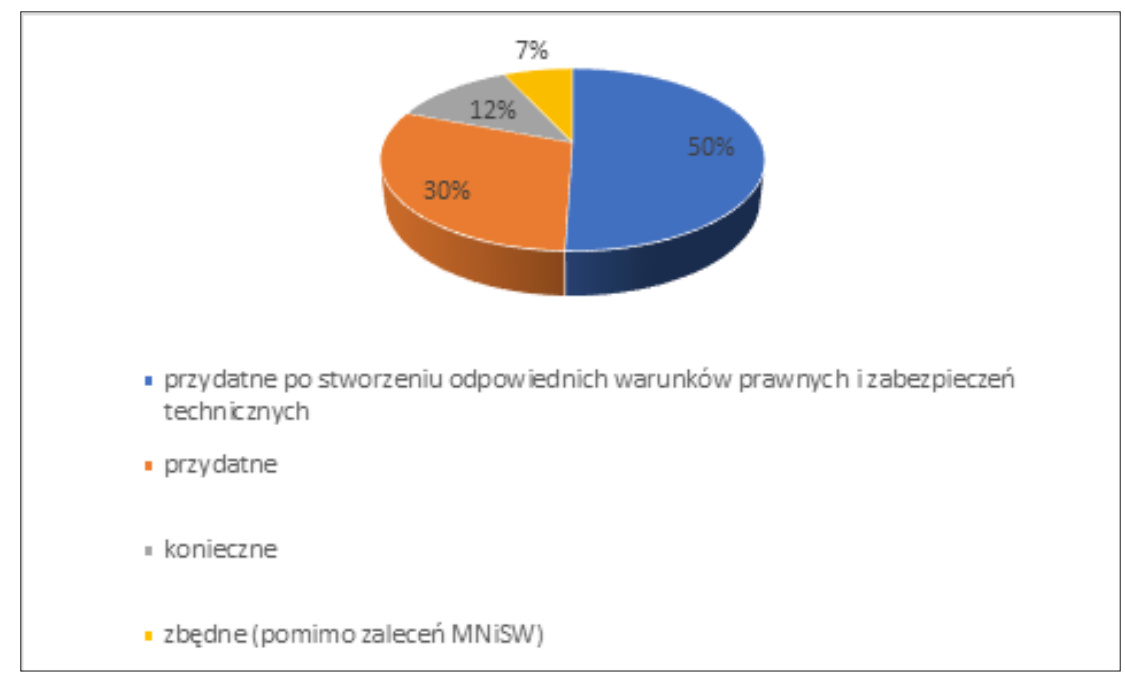

Ryc. 16. Odpowiedź na pytanie:

Proszę dokończyć zdanie: Repozytorium uczelniane uważam za: ...

Respondenci uważają Repozytorium za przydatne, ale po stworzeniu odpowiednich warunków prawnych i zabezpieczeń technicznych. Uważają tak 122 osoby, czyli ponad połowa ankietowanych. Jako przydatne określiły go 74 osoby, czyli 30\% ankietowanych, jako konieczne 30 osób (12\%), a jako zbędne, pomimo zaleceń MNiSW - 17 osób, co stanowi 7\% badanych.

Pytanie 11: Czy chciałaby Pani / chciatby Pan zdeponować w powstającym Repozytorium AGH?

- tak,

- nie mam zdania.

- nie. 


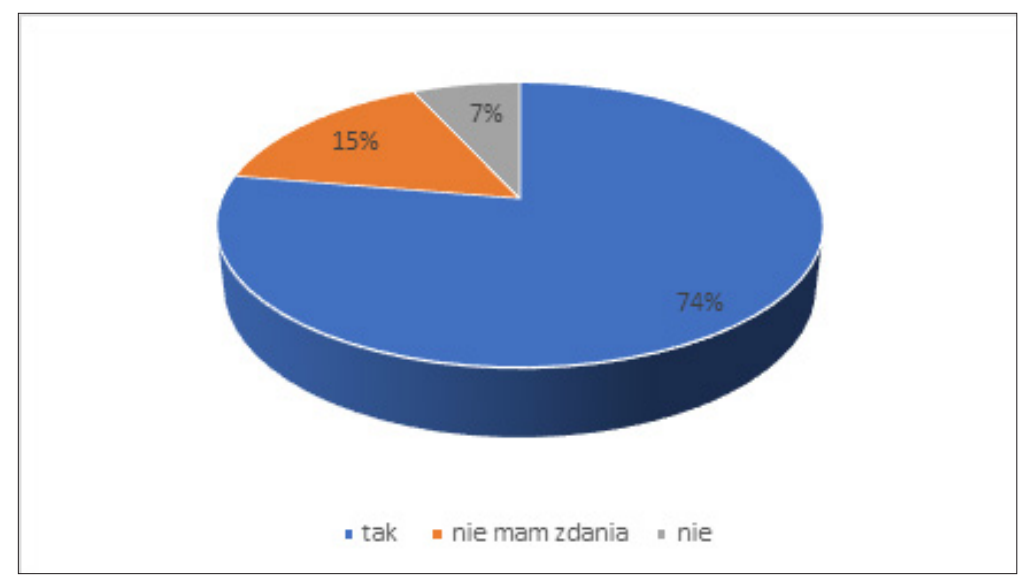

Ryc. 17. Odpowiedź na pytanie:

Czy chciałaby Pani / chciałby Pan zdeponować w powstajqcym Repozytorium AGH?

Zdecydowana większość - 74\% - ankietowanych chciałaby zdeponować publikacje w powstającym Repozytorium. 15\% czyli 36 osób nie ma zdania, natomiast 16 osób, czyli 7\% badanych nie chciałoby tego robić.

Część 3. Pytania dodatkowe i pomocnicze

Pytanie 1: W jakich zakresach oczekiwałaby Pani / oczekiwatby Pan wspótpracy lub pomocy ze strony administratorów Repozytorium?

- prawo autorskie,

- wybór licencji dla swojej pracy,

- sposób wprowadzania prac do systemu,

- korzystanie z bazy (wyszukiwanie informacji itp.),

- organizacja szkolenia odnośnie wprowadzania prac.

81\% respondentów oczekiwałoby pomocy z zakresu prawa autorskiego. 165 osób (67\%) potrzebuje pomocy w zakresie wyboru licencji dla swojej pracy. Dla 57\% ważny jest sposób wprowadzania prac do systemu, 33\% potrzebowałaby współpracy przy korzystaniu z bazy, np. wyszukiwanie informacji, a 30\% potrzebowałoby organizacji szkolenia odnośnie wprowadzania prac do systemu. 


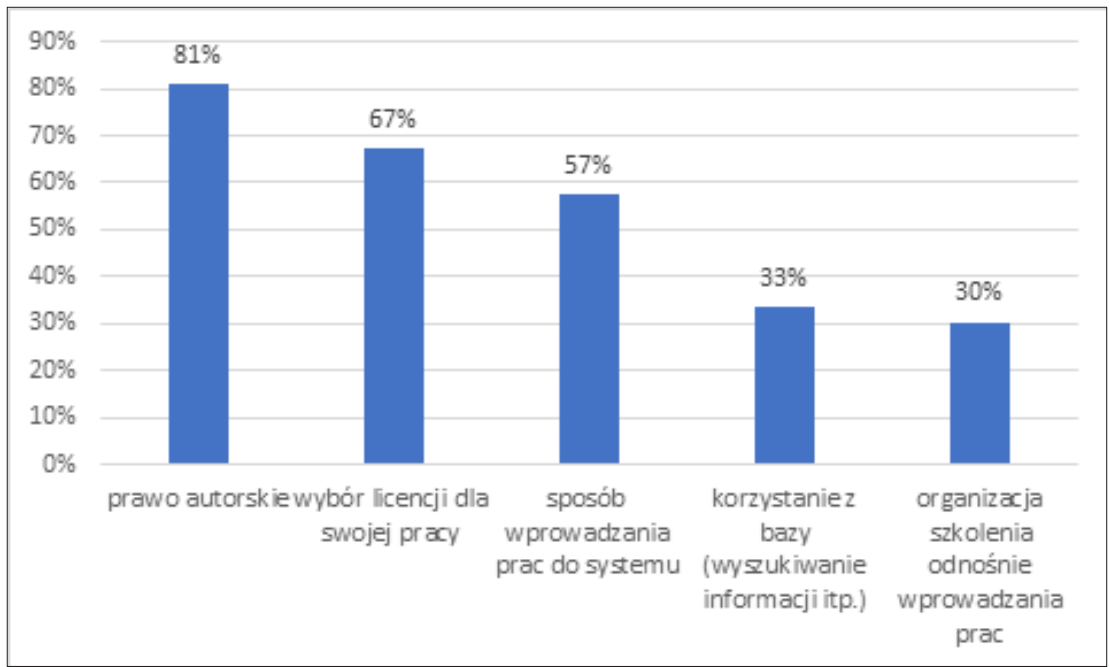

Ryc. 18 Odpowiedź na pytanie: W jakich zakresach oczekiwałaby Pani / oczekiwałby Pan współpracy lub pomocy ze strony administratorów Repozytorium?

Pytanie 2: Czy chciałaby Pani / chciałby Pan wziać udział w ewentualnym testowaniu interfejsu powstającego Repozytorium AGH? Jeżeli tak, prosze wpisać poniżej swój adres e-mail. Jeżeli nie, prosze pozostawić puste pole.

Do badania zgłosiło się 30\% ankietowanych czyli 73 osoby.

\section{Podsumowanie i dyskusja}

W badaniu najliczniej wzięli udział doktorzy, którzy stanowili 56\% wszystkich badanych. Przeciętny respondent to doktor do 45 roku życia, pracujący od 11 do 20 lat na uczelni. Była to najbardziej aktywna grupa, zamieszczająca wiele ciekawych opinii w wolnych komentarzach. W badaniu udział wzięło 20 wydziałów i jednostek uczelni. Najliczniej udział wzięli pracownicy Wydziału Elektroniki, Automatyki, Informatyki i Inżynierii Biomedycznej oraz Wydziału Informatyki, Elektroniki i Telekomunikacji - 30 osób (12\%). 79\% respondentów znało termin „repozytorium instytucjonalne”, z czego najwięcej było wśród doktorantów - 96\%, następnie doktorów habilitowanych - 85\%, doktorów 82\% oraz profesorów 79\%. Respondenci w większości zapoznali się z przesłanymi materiałami - 84\%. Znaleźli się również tacy, którzy nie wiedzieli o istnieniu 
takiego terminu, a zapoznali się z materiałami. Ankieta spełniła więc też funkcję edukacyjną $-6 \%$ respondentów.

Respondenci najczęściej dotychczas publikowali swoje dotychczasowe prace w serwisach społecznościowych dla naukowców, a wśród doktorów odpowiedziało tak prawie $67 \%$. Mniej popularne wśród tej grupy są czasopisma naukowe, które zaznaczyło $62 \%$ doktorów. Co ciekawe - tendencja odwrotna widoczna jest wśród profesorów, gdzie najczęściej pojawiają się czasopisma elektroniczne 52\% profesorów, a serwisy społecznościowe - 45\%. Wśród komentarzy najczęściej pojawiał się serwis społecznościowy ResearchGate ${ }^{7}$, który następnie wielokrotnie wskazywany był jako wzór do naśladowania podczas tworzenia interfesju Repozytorium. Powszechnie znany jest termin Open Access - potwierdziło to prawie $94 \%$ ankietowanych. Trzy typy prac, które wg ankietowanych powinny się znaleźć w repozytorium to artykuły naukowe, rozprawy doktorskie i habilitacyjne oraz materiały konferencyjne. Ankietowani w komentarzach wymieniali również wykłady, nagrania radiowe, tutoriale, kody źródłowe oprogramowania czy załączniki do artykułów. Doktorzy opowiedzieli się za artykułami naukowymi w $85 \%$, natomiast profesorowie w przeszło 90\%. Rozprawy doktorskie i habilitacyjne okazały się być równie ważne co artykuły naukowe zarówno dla profesorów (90\%), jak i doktorów (78\%). Dla doktorantów ważniejsze są rozprawy doktorskie niż artykuły naukowe - odpowiednio 81\% i 77\% tej grupy naukowej. Odpowiedziało tak $81 \%$ doktorantów, natomiast w przypadku artykułów było to 77\% tej grupy naukowej. Respondenci na pytanie o sposób dostępności materiałów w repozytorium nie byli całkowicie zgodni. 46\% uznało, że powinny być dostępne bez ograniczeń, 39\%, że powinny być dostępne dla zdefiniowanej grupy odbiorców, 34\%, że powinny być dostępne dla wszystkich z możliwością wskazania przez autora daty publikacji, natomiast $13 \%$, że powinny być dostępne tylko dla nich samych. Jednakże kiedy spojrzymy na te dane pod kątem grup naukowych, okazuje się, że przeważająca liczba profesorów (62\%) oraz połowa doktorów habilitowanych jest za dostępnością prac bez ograniczeń. Doktorzy opowiedzieli się zarówno za dostępnością materiałów bez ograniczeń jak i za dostępnością dla zdefiniowanej grupy odbiorców (44\%). Dla ponad połowy doktorantów z kolei ważna jest dostępność dla wszystkich, ale z możliwością wskazania daty publikacji (54\%). Ponad połowa respondentów (56\%) twierdzi, że autoarchiwizacja powinna być nieobowiązkowa. Twierdzi tak 66\% osób z grupy profesorów i 54\% z grupy doktorów, natomiast dla doktorantów jest ona ważna, ponad połowa (58\%) uważa, że powinna być obowiązkowa.

\footnotetext{
7 https://www.researchgate.net/
} 
Doświadczenie światowe pokazuje, że brak autoarchiwizacji znacząco wpływa na liczbę deponowanych dokumentów - w tym przypadku do repozytorium trafia tylko $15 \%$ dorobku naukowego ${ }^{8}$. Dlatego należy zwrócić na to uwagę podczas akcji promocyjnych repozytorium AGH. Wśród 5 najważniejszych powodów, które respondenci wymienili jako motywujące znalazły się: wzrost cytowań (66\%), trwałe zabezpieczenie dokumentu, archiwizacja dokumentu, niezmienny adres dostępu (64\%), zwiększenie widoczności pracy w środowisku naukowym (59\%), promocja osiągnięć autora i jednostki macierzystej (59\%) oraz szybkie upowszechnienie wyników pracy (54\%). Doktorów najbardziej motywuje wzrost cytowań - 70\% respondentów z grupy, doktorów habilitowanych - zwiększenie widoczności pracy w środowisku naukowym - 64\% osób z grupy. Wśród profesorów przeważa promocja osiągnięć autora i jednostki macierzystej - 72\% osób z grupy, a doktorantów najbardziej motywuje trwałe zabezpieczenie dokumentu, archiwizacja dokumentu i niezmienny adres dostępu - 69\% z grupy. Potwierdzają się tutaj badania wykonane w 2005 r. przez Foster i Gibbons nad motywacjami środowiska akademickiego do współtworzenia repozytorium, w których wyniki były bardzo podobne ${ }^{9}$ - główną motywacją było umożliwienie innym naukowcom do korzystania i cytowania swoich prac. Z nietypowych funkcjonalności respondenci najchętniej widzieliby możliwość wysłania wiadomości do danego autora bezpośrednio przez system - 76\% ankietowanych. Za taką opcją opowiedziało się 85\% osób w grupie doktorantów, $81 \%$ osób w grupie doktorów habilitowanych oraz $77 \%$ osób z grupy doktorów. Ponad połowa ankietowanych (53\%) najbardziej obawiała się plagiatu i nieuprawnionego wykorzystania wyników badań. Na kolejnych 2 miejscach znajduje się niewystarczająca znajomość zagadnień prawnych związanych z publikacją prac w Internecie (43\%) oraz konieczność wygospodarowania dodatkowego czasu do nauki systemu i wprowadzania swoich publikacji (38\%). Doktorzy, doktorzy habilitowani oraz profesorowie najbardziej obawiają się plagiatu oraz nieuprawnionego użycia wyników badań - jest to odpowiednio $58 \%$ badanych doktorów i 45\% badanych doktorów habilitowanych. Tego samego obawiają się doktoranci (38\%), a także niewystarczającej znajomości zagadnień prawnych (38\%). Kwestie dotyczące braku czasu na naukę systemu

${ }^{8}$ A. Sale, Comparison of IR content policies in Australia, „First Monday”, t. 11 (4), 2006, http://eprints.utas.edu.au/264/1/Comparison_of_content_policies_in_Australia. pdf (dostęp 10 X 2017 r.)

9 N. F. Foster, S. Gibbons, Understanding faculty to improve content recruitment for institutional Repositories, „D-Lib Magazine”, t. 11, 2005, nr 1, http://www.dlib.org/dlib/ january05/foster/01foster.html (dostęp 10 X 2017 r.) 
zgłosiło najwięcej doktorów (42\%). Jest to spowodowane wieloma obowiązkami, nie tylko naukowymi, z jakimi mierzą się codziennie. W tym przypadku również potwierdzają się wyniki badań wspomnianych wcześniej autorek - w ich badaniach autorzy najbardziej obawiali się dodatkowych obowiązków oraz naruszenia praw autorskich. Podobne wyniki osiągnięto również na UAM, gdzie ankietowani najbardziej obawiali się naruszenia praw autorskich ${ }^{10}$. Respondenci w dużej mierze sami wolą wprowadzać swoje prace - tą opcję zaznaczyło 62\% badanych. A już 20\% mniej opowiedziało się za opcją redaktorów Repozytorium w Bibliotece głównej. Ciekawym jest fakt, że pomimo obaw i narzekań na konieczność wygospodarowania czasu do nauki systemu większość ankietowanych sama chciałaby wprowadzać swoje dane - opowiedziało się za tą opcję $60 \%$ osób z grupy doktorów, 57\% z grupy doktorów habilitowanych, przeszło 85\% respondentów z grupy profesorów i 55\% osób z grupy doktorantów. Widać tutaj wyraźnie, że ankietowani chcą mieć jak największą sprawczość w przypadku udostępniania swoich badań. Badania wykazały, że połowa ankietowanych uważa Repozytorium za przydatne, ale dopiero po stworzeniu odpowiednich warunków prawnych i technicznych potwierdzając tym samym swoje 3 główne obawy związane z Repozytorium. Bardzo pozytywnym faktem jest to, że 74\% osób badanych wyraziło chęć zdeponowania swoich dokumentów w powstającym Repozytorium. Można więc mieć nadzieję, że Repozytorium instytucjonalne AGH będzie cieszyło się popularnością wśród, pracowników naukowych AGH.

\section{Wnioski}

1. Badania ankietowe wykazały, jak bardzo ważna jest współpraca i dialog pomiędzy środowiskiem tworzącym a środowiskiem korzystającym z Repozytorium. Cenne wskazówki przekazane przez respondentów przełożą się na potwierdzenie lub podważenie ważności konkretnych funkcji w Repozytorium. Wiele z nich wskazało także kierunek, w jakim system powinien rozwinąć się w przyszłości.

2. Wszystkie osoby, które zgłosiły się do testowania interfejsu zostaną do tego zaangażowane. W tym celu opracowane zostaną scenariusze użycia oraz

${ }^{10}$ M. Rychlik, E. Karwasińska, Polowanie na zasób - czyli strategia pozyskiwania dokumentów do repozytorium AMUR (Adam Mickiewicz University Repository), http://eprints. rclis.org/17305/1/RychlikM_KarwasinskaE_PolowanieZasob.pdf (dostęp 10 X 2017r.) 
sposób możliwego wytestowania funkcjonalności oraz wyglądu interfesju na żywym organizmie.

3. Największą obawą wśród środowiska naukowego związaną z udostępnianiem swojej pracy jest niedostateczne zabezpieczenie pracy, co może przyczynić się do niepowołanego wycieku danych, plagiatu czy nawet kradzieży wyników i opracowania badań. Przeciwdziałaniem i rozwianiem wszelkich obaw będzie stworzenie odpowiedniego systemu zabezpieczeń, które uniemożliwią jakąkolwiek ingerencję osób niepowołanych w dane zamieszczone w Repozytorium AGH.

4. Badani często podkreślali brak czasu oraz potrzebę wypełniania kilkukrotnie tych samych danych i formularzy jako czynniki zniechęcające ich do publikowania swoich danych w Internecie. Rozwiązaniem w tym przypadku jest stworzenie spójnego, funkcjonalnego i zintegrowanego systemu, który umożliwiałby przy jednokrotnym wprowadzaniu danych pojawianie się ich w innych miejscach przeznaczonych do publikacji pracy naukowej.

5. Repozytorium AGH powinno dawać autorom swobodę kontroli nad swoimi publikacjami. Respondenci stwierdzili w większości, że powinno ono dawać pełny dostęp do materiałów, ale tylko za zgodą ich autorów. Dzięki temu ich profil naukowy będzie publiczny i powszechny.

6. Termin 'open access' lub 'otwarty dostęp do nauki' jest terminem powszechnie znanym wśród przebadanej grupy co może sugerować podobny poziom wiedzy na całej uczelni. Szkolenia w kierunku poprawy poziomu znajomości zasad otwartego dostępu do nauki nie są konieczne w tym momencie.

7. Liczne obawy związane $\mathrm{z}$ publikowaniem $\mathrm{w}$ sieci swoich prac powiązane są z nieświadomą niewiedzą dotyczącą zagadnień prawa autorskiego i licencji dla poszczególnych typów prac, licencji podpisywanych wraz z wydawcą. Rozwiązaniem są tutaj szkolenia, prezentacje, instrukcje step-by-step, pomoc przy wprowadzaniu i wyborze licencji, a nawet stworzenie szkolenia w postaci e-learnigu, po które naukowiec mógłby sięgnąć o każdej porze, nie tracąc swojego czasu w ciągu codziennych zajęć.

8. Dla respondentów ważna jest komunikacja bezpośrednia pomiędzy autorami i użytkownikami oraz budowanie własnego wizerunku jako naukowca-specjalisty w konkretnej dziedzinie. Dobrym rozwiązaniem byłoby stworzenie swojego rodzaju elektronicznego CV, gdzie przeglądający mogliby znaleźć aktywność naukową danego autora.

9. Doceniając wagę pozytywnego nastawienia środowiska akademickiego, jego gotowość do dostarczania treści do repozytorium, rozwiązanie problemów wydaje się być kluczowe przy realizacji projektu repozytorium uczelnianego. 
10. Dla doktorów, czyli dla najbardziej aktywnej grupy naukowej w ankiecie, najbardziej liczy się aspekt społeczny i prezentacja własnego wizerunku jako naukowca, który generuje wartościowe artykuły, warte cytowania. Warto zwrócić uwagę na ten aspekt podczas planowania rozbudowy interfesju i funkcjonalności.

11. Ankieta oraz załączone w niej materiały nieoczekiwanie spełniły również funkcje edukacyjne. Znalazły się osoby, które nie wiedziały czym jest repozytorium, a zapoznały się z załączonymi materiałami, po czym wypełniły ankietę.

12. Większość doktorantów oczekuje, że autoarchiwizacja będzie obowiązkowa. Motywuje ich ku temu trwałość dokumentów i oraz ich bezpieczeństwo. Dodatkowo w jednym miejscu zebrane będą wszystkie ich prace, co często przydaje się w przypadku otrzymania grantu lub finansowania zewnętrznego.

\section{Literatura}

Foster N. F., Gibbons S., Understanding faculty to improve content recruitment for institutional Repositories, „D-Lib Magazine”, t. 11, 2005, nr 1, http://www.dlib.org/dlib/ january05/foster/01foster.html (dostęp 10 X 2017 r.)

Karwasińska E., Rychlik M., Budowanie repozytorium, http://hdl.handle.net/10593/2874 (dostęp 10 X 2017 r.)

Karwasińska E., Rychik M., Doświadczenia z funkcjonowania pierwszego w Polsce repozytorium instytucjonalnego na Uniwersytecie im. Adama Mickiewicza w Poznaniu, http:// hdl.handle.net/10593/6498 (dostęp 10 X 2017 r.)

Karwasińska E., Rychlik M., Model i etapy tworzenia repozytorium instytucjonalnego na podstawie badań własnych i doświadczeń bibliotek zagranicznych, 2008, [w:] Informacja dla nauki a świat zasobów cyfrowych, red. H. Ganińska, Poznań 2008.

OpenDOAR. The Directory of Open Access Repositories, http://www.opendoar.org/ onechart.php cID $=\& \mathrm{ctID}=\& \mathrm{rtID}=\& \mathrm{clID}=\& \mathrm{IID}=\&$ potID $=\& \mathrm{rSoftWareName}=\&$ search $=\&$ groupby $=$ r.rSoftWareName\&orderby $=$ Tally\%20DESC\&charttype $=$ pie $\&$ width $=600 \&$ height $=300 \&$ caption $=$ Usage $\% 20$ of $\% 200$ pen $\% 20$ Access $\% 20$ Repository\%20Software\%20-\%20Worldwide (dostęp dnia 10 X 2017 r.)

Rychlik M., Karwasińska E., Polowanie na zasób - czyli strategia pozyskiwania dokumentów do repozytorium AMUR (Adam Mickiewicz University Repository), http://eprints.rclis. org/17305/1/RychlikM_KarwasinskaE_PolowanieZasob.pdf (dostęp 10 X 2017 r.)

Sale A., Comparison of IR content policies in Australia, „First Monday”, t. 11 (4), 2006, http://eprints.utas.edu.au/264/1/Comparison_of_content_policies_in_Australia. pdf (dostęp 10 X 2017 r.), http://eprints.utas.edu.au/264/1/Comparison_of_content_policies_in_Australia.pdf

Stąporek M., Organizacja i funkcjonalność wiarygodnego archiwum cyfrowego uczelni wyższej na Przykładzie Politechniki Krakowskiej, [w:] Wokót zagadnień trwałej ochrony zasobów cyfrowych, red. A. Januszko-Szakiel, Kraków 2013. 


\section{Summary}

Repository of AGH University of Science and Technology - experiences and attitudes of research staff of AGH University of Science and Technology

The aim of the stude is presentation of research conclusions concerning experiences and attitudes of members of research staff of AGH academic circles towards already existing repositories and bases of publications, as well as their attitude to the Repository of AGH, currently under construction. The research is based on electronic surveys, designed to study also the academic circles' expectations of the system and its interface. The survey was prepared and designed used Lime Survey, a tool that enables disclosing it on-line in an electronic form; afterwards it was e-mailed to chosen research groups. The e-mail contained invitation to cooperation with the constructed Repository, a link to the survey and a link to educational materials about bases of publications. This article presents results, observations and conclusions drawn from analysis of gathered data. 